\title{
Spatiotemporal variability and trends in rainfall and temperature in Alwero watershed, western Ethiopia
}

\author{
Arragaw Alemayehu1*, Molla Maru², Woldeamlak Bewket ${ }^{2}$ and Mohammed Assen²
}

\begin{abstract}
Climate analysis at relevant time scales is important for water resources management, agricultural planning, flood risk assessment, ecological modeling and climate change adaptation. This study analyses spatiotemporal variability and trends in rainfall and temperature in Alwero watershed, western Ethiopia. Our analysis is focused on describing spatial and temporal variability of rainfall in the study area including detection of trends, with no attempt at providing meteorological explanations to any of the patterns or trends. The study is based on gridded monthly rainfall and maximum and minimum temperature data series at a resolution of $4 \times 4 \mathrm{~km}$ which were obtained from the National Meteorological Agency of Ethiopia for the period 1983-2016. The study area is represented by 558 points (each point representing $4 \times 4 \mathrm{~km}$ area). Mean annual rainfall of the watershed is $>1600 \mathrm{~mm}$. Annual, June-September (Kiremt), March-May (Belg) rainfall totals exhibit low inter-annual variability. Annual and October-February (Bega) rainfalls show statistically significant increasing trends at $p=0.01$ level. May and November rainfall show statistically significant increasing trends at $p=0.01$ level. March shows statistically significant decreasing trend at $p=0.1$ level. The mean annual temperature of the watershed is $25^{\circ} \mathrm{C}$ with standard deviation of $0.31{ }^{\circ} \mathrm{C}$ and coefficient of variation of $0.01{ }^{\circ} \mathrm{C}$. Mean annual minimum and maximum temperatures show statistically non-significant decreasing trends. Bega season experienced statistically significant deceasing trend in the maximum temperature at $p=0.01$ level. The year-to-year variability in the mean annual minimum and maximum temperatures showed that the 2000s is cooler than the preceding decades. Unlike our expectations, annual and seasonal rainfall totals showed increasing trends while maximum and minimum temperatures showed decreasing trends. Our results suggest that local level investigations such as this one are important in developing context-specific climate change adaptation and agricultural planning, instead of coarse-scale national level analysis guiding local level decisions.
\end{abstract}

Keywords: Rainfall and temperature trends, Climate variability, Alwero watershed, Ethiopia

\section{Background}

Climate change is increasing the occurrence and magnitude of rainfall extremes that cause increased drought and flood risks (Chen et al. 2014). The influence of current climate variability on crop production is large in developing countries like Ethiopia where agriculture is primarily dependent on rainfall (Alemayehu and Bewket

\footnotetext{
*Correspondence: arragawalex@gmail.com

${ }^{1}$ Department of Geography \& Environmental Studies, Debre Berhan

University, Debre Birhan, Ethiopia

Full list of author information is available at the end of the article
}

2016a). Rainfall in Ethiopia shows high variability across space and time owing to the complex topography varying from 120 mbsl to 4620 masl (Reda et al. 2015) and latitude of the country varying from 3 to $15^{\circ} \mathrm{N}$ and $33^{\circ} \mathrm{E}$ to $48^{\circ} \mathrm{E}$ (Gamachu 1988). Robust information on the seasonality of rainfall in the country is important to tackle its adverse economic and social consequences including on agriculture (Korecha 2013) and for local level climate change adaptation planning (Alemayehu and Bewket 2017a). The rainfall pattern in Ethiopia is strongly seasonal (World Bank 2006). It is characterized by wet and long rainy seasons on the one hand and long dry and 
short rainy seasons on the other hand (World Bank 2006; Korecha 2013). Consequently, the high and low rainfall phenomena can give rise respectively to flood and drought conditions with adverse economic and humanitarian crises (World Bank 2006). In Ethiopia, the performance of the agricultural sector and the rainfall pattern show strong correlations (Admassu 2004; Lemi 2005; World Bank 2006; Bewket 2009; Conway and Schipper 2011; Alemayehu and Bewket 2016a). Rainfall shortage often leads to famines (Alemayehu and Bewket 2017b).

There are three seasons in Ethiopia. These are (i) the June-September (main rainy season, locally known as Kiremt); (ii) the March-May (short rainy season, locally known as Belg); and the October - February (dry season, locally known as Bega) (Seleshi and Zanke 2004; Alemayehu and Bewket 2017a). Understanding the characteristics of Kiremt and Belg season rainfall is useful for improving agricultural productivity and mitigating food security challenges (Alemayehu and Bewket 2016a, a; Mulugeta et al. 2019) and water resource development of the country (Degefu and Bewket 2014; Suryabhagavan 2017). Kiremt rainfall which is the largest in terms of its amount and geographical coverage is less variable in most parts of the country compared to Belg and Bega season rainfall (Shankoa and Camberlin 1998). It supports the main cropping season production, locally known as Meher. Kiremt rainfall shortage or change impacted the agricultural productivity in the country (Mulugeta et al. 2019).

The Belg season rainfall is characterized by high temporal and spatial variability, which has implications on Belg season crops and food security of households (Alemayehu and Bewket 2016a; Bekele-Biratu et al. 2018). The change and shift in Belg season rainfall leads to devastating droughts affecting socioeconomic welfare and environmental resources (Haile et al. 2019).

Alemayehu and Bewket (2017a) summarized previous studies on rainfall and temperature variability and trends in Ethiopia covering different temporal and spatial scales. They concluded that studies on rainfall did not show clear trend for the country. The possible explanations to that are: (i) trends in annual and seasonal rainfalls are affected by topography (Bewket and Conway 2007; Mengistu et al. 2013); (ii) trend analysis is largely sensitive to quality of data, the choice of study periods and stations considered by the different studies (Seleshi and Zanke 2004; Bewket and Conway 2007; Mengistu et al. 2013); (iii) the northsouth oscillation of the Inter Tropical Convergence Zone (ITCZ), the El Ni no-Southern Oscillation (ENSO) phenomena (Shanko and Camberlain 1998; Seleshi and Zanke 2004; Gleixner et al. 2017) and fluctuations in sea surface temperatures (SSTs) mask trends (Shanko and Camberlain 1998; Gissila et al. 2004; Segele and Lamb
2005; Viste et al 2012; Jury and Funk 2013); and (iv) previous studies on variability and trends in rainfall and temperature frequently takes place at large scale (Ademe et al. 2020) and contributed to mixed patterns of change.

Despite the discrepancies observed, a growing number of studies in Ethiopia reported downward trend in seasonal and annual rainfall totals (e.g., Shanko and Camberlin 1998; NMA 2007; Osman and Sauerborn 2002; Seleshi and Zanke 2004; Verdin et al. 2005; Cheung et al. 2008; Viste et al. 2012; Jury and Funk 2013; Urgessa 2013; Wagesho et al. 2013; Addisu et al. 2015; Alemayehu and Bewket 2017a; Asaminew et al. 2017; Asfaw et al. 2018; Haile et al. 2019; Ademe et al. 2020; Matewos and Tefera 2020). Available studies on temperature reported warming trend in the maximum and minimum temperatures (e.g., NMA 2007; McSweeney et al. 2008; Taye and Zewdu 2012; Ayalew et al. 2012; Mengistu et al. 2013; Mekasha et al. 2014; Addisu et al. 2015; Alemayehu and Bewket 2017a; Asaminew et al. 2017; Suryabhagavan 2017; Asfaw et al. 2018; Haile et al. 2019; Ademe et al. 2020; Matewos and Tefera 2020). Climate analysis at relevant time scales is important for agricultural planning, water resources management, flood risk management, ecological modeling and climate change adaptation (Engida and Esteves 2011; Alemayehu and Bewket 2017a; Sun et al. 2018).

The focus of this study is to investigate the spatiotemporal variability and trends in rainfall and temperature in Alwero watershed in the western part of Ethiopia using a dense network of $4 \times 4 \mathrm{~km}$ gridded data (558 points) reconstructed from weather stations and meteorological satellite records which spatially covers the watershed. In countries like Ethiopia where a major underlying vulnerability factor is the heavy dependence of the economy on rain-fed smallholder agriculture (Conway and Schipper 2011; Alemayehu and Bewket 2016b), timely and accurate availability of climate information is useful for sustainable climate risk management (Alemayehu and Bewket 2017a). A better understanding of the changes in long-term annual and seasonal rainfall at local level is useful for adaptation intervention (Mulugeta et al. 2019). Local level investigations such as this one are important in developing context-specific climate change adaptation and agricultural planning, instead of coarse-scale national level analysis guiding local level decisions.

The study area in particular is the largest agricultural investment hub in the country where a detailed previous study does not exist. In the following section, we present a brief description of materials and methods of the study, and this is followed by the results and discussion section. Conclusions are presented in "Data and methods Section". 


\section{Materials and methods}

\section{Description of the study area}

Alwero watershed is found in the Abobo district of the Gambella National Regional State, western Ethiopia (Fig. 1). The Gambella Region is largely lowland (Kolla) agroecological zone with hot to warm humid climate. Mean annual rainfall is about $1200 \mathrm{~mm}$. Mean annual temperature is $26.7^{\circ} \mathrm{C}$ (Degife et al. 2019). The level of natural resource use is low due to sparse population density. The soil, topography and climate conditions have made the Region to be one of the most fertile parts of the country and highly suitable for growing various types of tropical crops. In the early 2000s, about 3.5 hectares of land from southwest part of the country which is also the present study area were leased to both domestic and foreign investors (Rahimato 2011). Since 2008 , the Region was prioritized as one of the biggest destination for large scale agricultural investment.
More than 1.2 hectares of land were transferred to both domestic and foreign investors (Rahimato 2011).

The altitude of Alwero watershed ranges from 385 to $2531 \mathrm{~m}$ asl (Fig. 1). About 58 and $40 \%$ of the watershed lies in altitude ranges of $385-500 \mathrm{~m}$ asl and $500-1837 \mathrm{~m}$ asl, respectively. Only about $2 \%$ of the watershed contains hills and escarpments located in the eastern edge of the watershed with an altitude range of 1837 to $2531 \mathrm{~m}$ asl. The eastern edge of the watershed is characterized by steep and very steep slopes whereas the central part is dominated by a mix of flat, gently sloping and sloping terrain. Alwero watershed has two sub-watersheds; upper (eastern) and lower (western). The altitude of the upper (eastern) sub-watershed ranges from 619 to $2531 \mathrm{~m}$ asl. The altitude of the lower (western) sub-watershed ranges from 385 to $619 \mathrm{~m}$ asl.

According to Zabel et al. (2014) Dystric and Eutric Plinthosols, Dystric and Chromic Cambisols, Eutric Vertisols and Planosols are the major soils of the district.

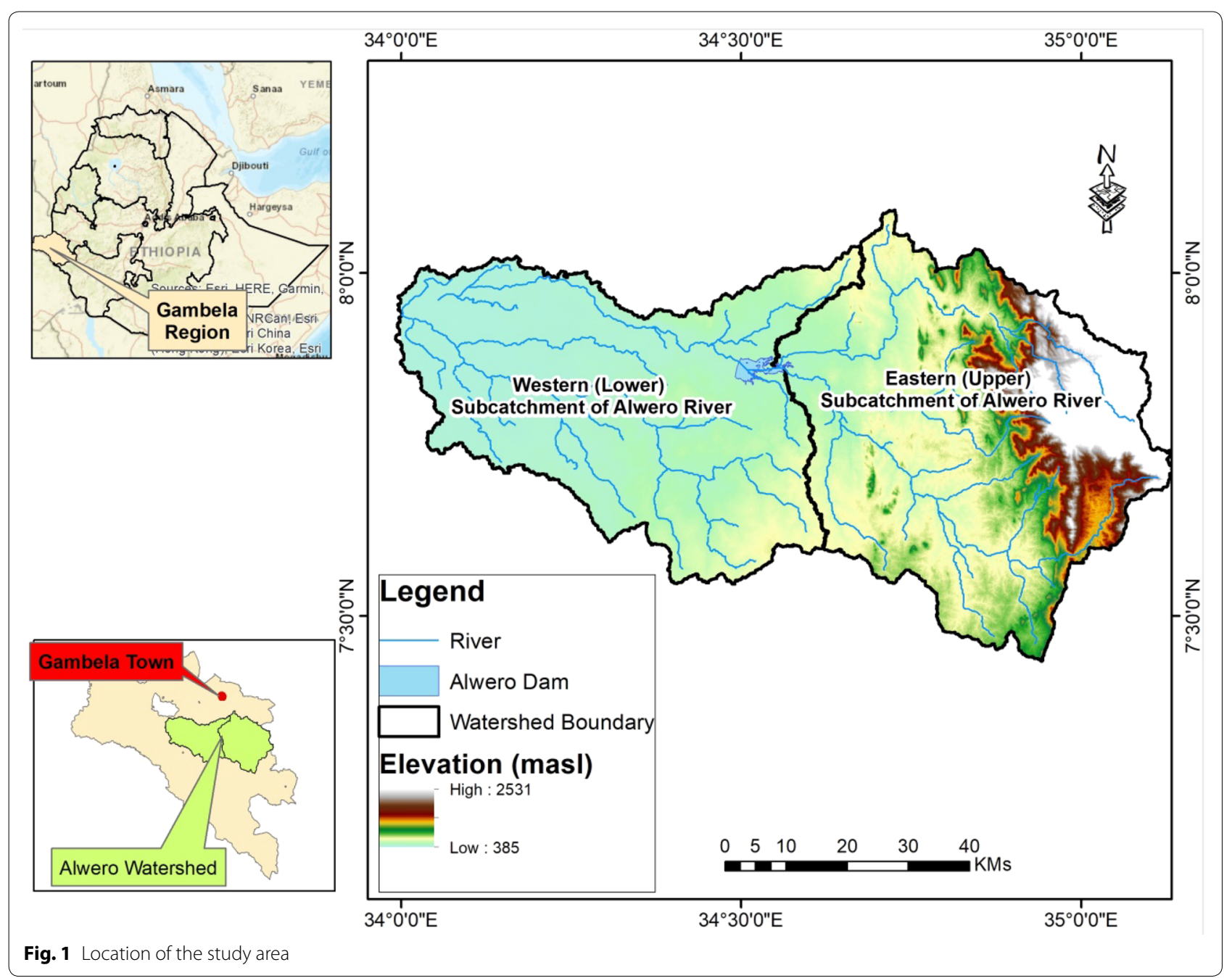


The major land use types of Abobo district include forest (143,086 ha), woodland (75,227 ha), shrub (5,793 ha), grass $(62,997 \mathrm{ha})$ and cultivated lands $(19,854 \mathrm{ha})$ (Yitbarek et al. 2017). Maize (Zea mays L.), sorghum (Sorghum bicolor), groundnut (Arachis hypogae), sesame (Sesamum astivum), cotton (Gossypium sp.) and rice (Oryza sativa L.) are major crops grown in the area (Yitbarek et al. 2017). From these, maize and sorghum are the dominant in terms of production (Degife et al. 2019) and consumption (Dorosh and Rashid 2013).

According to the Central Statistical Authority (CSA) (2013), the total population of Abobo district is 22,420 out of which 11,531 are males and 10,889 are females. Of the total, about 35\% resides in urban area (Abobo town) and the remaining $65 \%$ lives in rural areas. The livelihood of the population in the watershed is largely dependent on small-scale farming, fishing, retailing and casual jobs in large-scale farms, construction and government and non-government offices.

\section{Data and methods}

The study is based on gridded monthly rainfall and temperature data series at a resolution of $4 \times 4 \mathrm{~km}$ for the period 1983-2016. The study area is covered by 558 points (each representing $4 \times 4 \mathrm{~km}$ area). The data are created by blending station records with meteorological satellite estimates and were obtained from the National Meteorological Agency of Ethiopia. This is the best available dataset for the country which is homogeneous and recommended for climate analysis (Dinku et al. 2014). In recent years, gridded rainfall and temperature datasets have been used in Ethiopia with different data sources and spatial resolutions (Mengistu et al. 2013; Dinku et al. 2014; Alemayehu and Bewket 2017a; Mulugeta et al. 2019; Gebrechorkos et al. 2020; Ademe et al. 2020; Matewos and Tefera 2020).

Coefficient of variation (CV), precipitation concentration index (PCI) and standardized rainfall anomaly (SRA) are used to examine inter-annual and intra-annual variability of rainfall. The CV measures year-to-year variation in the data series. According to NMA (1996) classification, $\mathrm{CV}$ less than 0.20 is less variable, $\mathrm{CV}$ between 0.20 and 0.30 is moderately variable and $\mathrm{CV}$ greater than 0.30 indicates high variability. The PCI values measure extent of seasonality of rainfall; and it is given as indicated in De Luis et al. (2000):

$$
\mathrm{PCI}=100 \times\left[\sum \mathrm{Pi}^{2} /\left(\sum \mathrm{Pi}\right)^{2}\right]
$$

where: $\mathrm{Pi}=$ the rainfall amount of the ith month; and $\Sigma \mathrm{Pi}^{2}=$ summation over the 12 months. PCI values of less than 10 indicate quite uniform monthly distribution of rainfall, values between 11 and 20 indicate moderate concentration, and values above 21 indicate high concentration.

SRA is commonly used as a simple index to characterize drought at different time scales, or to identify abnormal wetness or dryness (Guttman 1999). SRA values are given as;

$$
\mathrm{SRA}=(\mathrm{Pt}-\mathrm{Pm}) / \sigma
$$

where $\mathrm{SRA}=$ standardized rainfall anomaly, $\mathrm{Pt}=$ annual rainfall in year $\mathrm{t}, \mathrm{Pm}=$ is long-term mean annual rainfall over a period of observation and $\sigma=$ standard deviation of annual rainfall over the period of observation. According to Agnew and Chappel (1999), SRA values indicate extreme drought (SRA $<-1.65)$, severe drought $(-1.28>\mathrm{SRA}>-1.65)$, moderate drought $(-0.84>\mathrm{SRA}>-1.28)$, and no drought (SRA $>-0.84)$. Linear regression was used to detect trends in rainfall. It is given as;

$$
\mathrm{Y}=\mathrm{mx}+\mathrm{b}
$$

where $y$ is dependent variable, $\mathrm{m}$ is the slope, $\mathrm{x}$ is independent variable and $\mathrm{b}$ is the intercept. F-distribution test was applied to determine the statistical significance of the trends. The minimum and maximum temperatures were also analyzed using the above techniques. Surface data were generated from the gridded monthly rainfall and temperature data using kriging interpolation technique with the help of ArcGIS 10.1.

\section{Results and discussion}

Rainfall variability and trends in Alwero watershed Annual and seasonal rainfall patterns

Mean annual rainfall of Alwero watershed is $1665.5 \mathrm{~mm}$ (Table 1), and its inter-annual variability is low with a CV of 8.7\%. The Kiremt and Belg rainfall also show low interannual variability (CV, 9.2\% and $19.7 \%$, respectively). Bega rainfall shows moderate variability (CV, 24\%). Previous studies on variability and trends of annual and seasonal rainfall reported moderate and high variability in their respective study areas (Bewket and Conway 2007; Ayalew et al. 2012; Alemayehu and Bewket 2017a, b; Hadgu et al. 2013; Urgessa 2013; Ademe et al. 2020).

As indicated by the PCI values, rainfall shows moderate concentration in few months of the year (10.8). It can be observed that above average mean monthly rainfall is recorded from May to October. These months have recorded above $130 \mathrm{~mm}$ rainfall (Fig. 2). About $80 \%$ of annual rainfall is concentrated in these six months which ranges from 11\% (October) to 14.4\% (August). August supplies the largest amount of rainfall in the watershed. July and September also represent high contributions to the annual totals. Our results corroborate the findings of (Alemayehu and Bewket 2017a). 
Table 1 Trends of annual and seasonal rainfall in Alwero watershed

\begin{tabular}{|c|c|c|c|c|c|c|c|c|}
\hline Parameter & Amount (mm) & Contribution (\%) & CV & LT & Wettest year & Driest year & HMR & $\mathrm{PCl}$ \\
\hline Annual & 1665.5 & & 0.087 & $66^{*}$ & 2011 & 1986 & 365.9 & 10.8 \\
\hline Kiremt & 932.9 & 56 & 0.092 & 0.63 & 2003 & 1995 & & \\
\hline Belg & 410.8 & 25 & 0.197 & 20.27 & 2014 & 1987 & & \\
\hline Bega & 321.9 & 19 & 0.241 & $45.09^{* *}$ & 2008 & 1984 & & \\
\hline
\end{tabular}

*Significant at 0.05 level; **Significant at 0.01 level; $L T$ linear trend ( $\mathrm{mm} / 10 \mathrm{yr}$ )

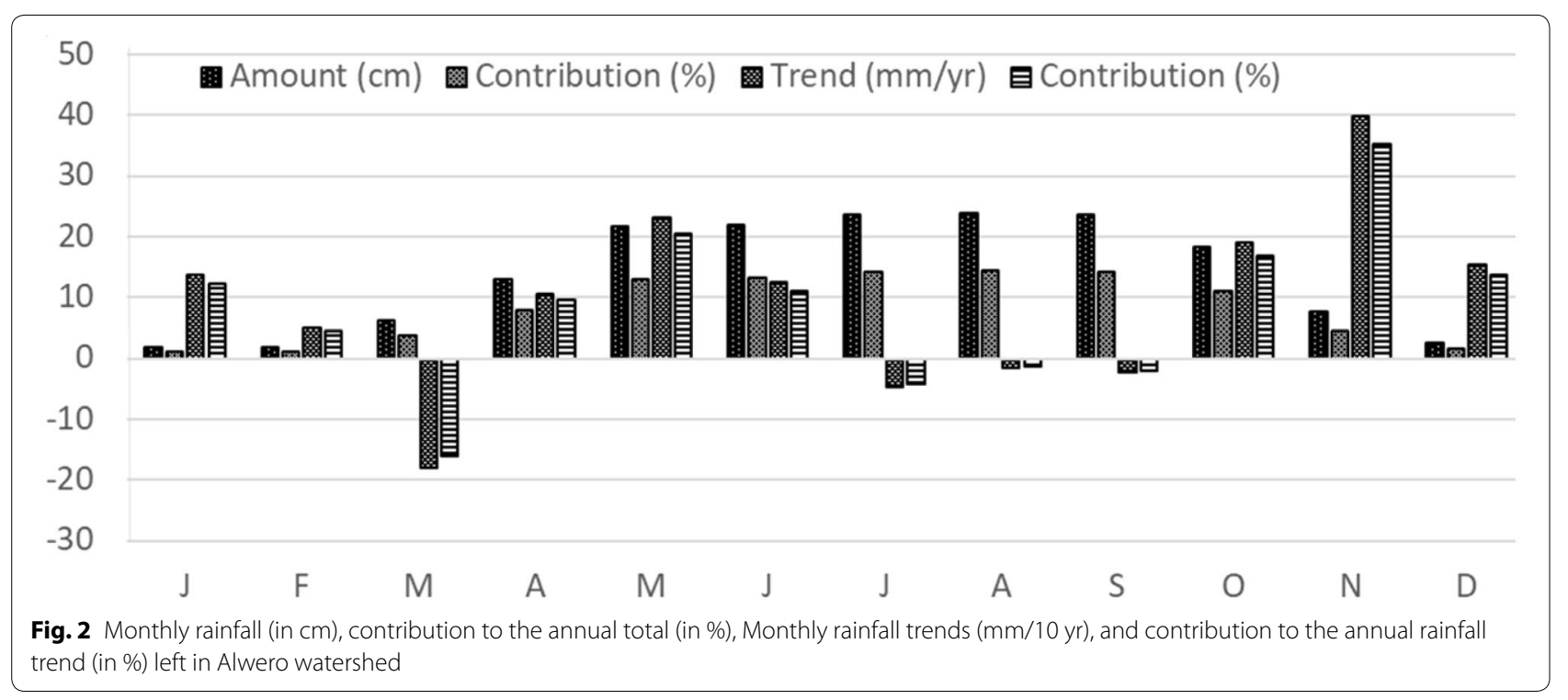

As elsewhere in Ethiopia, Kiremt rainfall contributes the largest to the annual rainfall (56\%), followed by Belg rainfall (25\%). Unlike other parts of the country, the contribution of Bega rainfall is high (19\%) as well. The highest monthly rainfall is $395.9 \mathrm{~mm}$ which accounted for $22 \%$ of the annual and $89 \%$ of Belg rainfall totals, respectively (Table 1). Unlike other areas of the country where high concentration of rainfall is recorded in the month of August followed by July, the highest monthly rainfall is recorded in May which is a dry month in most parts of the country. However, a recent study by Matewos and Tefera (2020) in the drought-prone districts of rural Sidama, central rift valley region of Ethiopia observed that April and May are the wettest months.

Annual and Bega rainfalls show statistically significant increasing trends at $p=0.1$ and $p=0.01$ levels, respectively. Kiremt and Belg rainfalls show no significant trends. These results contradict the findings of Shanko and Camberlin (1998), NMA (2007), Osman and Sauerborn (2002), Seleshi and Zanke (2004), Verdin et al. (2005), Cheung et al. (2008), Jury and Funk (2013), Urgessa (2013), Viste et al. (2012), Wagesho et al. (2013), Addisu et al. (2015), Alemayehu and Bewket (2017a),
Asaminew et al. (2017), Haile et al. (2019), Ademe et al. (2020) and Matewos and Tefera (2020) who reported declining trends of annual and seasonal rainfall totals in their respective study areas in different parts of the country. The statistically significant increasing trend of Bega rainfall supports the findings of a recent study by Matewos and Tefera (2020) who reported a significant increasing trend of Bega rainfall in the drought-prone districts of rural Sidama, central rift valley region of Ethiopia.

Regarding monthly rainfall trends, November and May showed statistically significant increasing trends at $p=0.05$ level. October shows significant increasing trend at $p=0.1$ level, and March shows significant decreasing trend at $p=0.1$ level (Fig. 2). June to September show non-significant increasing trends. December, January and February showed statistically non-significant increasing trends. March contributes the highest to the overall declining trend of annual rainfall while November makes considerable contribution to the overall increasing trend of annual rainfall.

In Ethiopia the driest year is 1984, which is the wellknown drought year. The wettest year is 2006 , which is the major flood year. The country has witnessed large 
scale losses of life and property during those periods. However, the driest and wettest years for Alwero watershed are 1986 and 2011, respectively. The wettest year for Kiremt is 2003, which is a recovery period from the second major drought period affecting large parts of the country. The years 2008 and 2014 are wettest periods for Bega and Belg seasons, respectively, while the dry years for Bega and Belg, respectively, are 1984 and 1987 (Table 1).

Figure 3 shows standardized annual and seasonal rainfall anomalies. Since 1983, annual rainfall showed declining trend up to 1990 except for the year 1988. Conversely, standardized rainfall anomalies are positive from 1990-1999 except the years 1994 and 1995. Annual rainfall shows considerable inter-annual variations between 2000 and 2009. From 2010 to 2016 standardized rainfall anomalies are positive except the year 2013. In the watershed, positive and negative anomalies account for $53 \%$ and $47 \%$ of the total observations, respectively. About $29 \%$ of the total number of observations is under the different drought categories. The 1990s is wet compared with the 1980 and 2000s. The results of this study are consistent with Bewket and Conway (2007) and McSweeney et al. (2008) who concluded the 1980s was drier than its preceding decade and the decades following.
Negative anomalies in Bega rainfall were observed from 1983-1995 except the years 1988 and 1992. Similarly, negative anomalies are observed from 2002-2007 except the year 2006, which is the major flood year in the country. Positive anomalies are observed from 1996-2001 and 2008-2016 except the year 2013. The proportion of positive and negative anomalies is equal and represents 50\% of the total observations. The 2000s is wetter than the preceding decades for Bega.

Kiremt rainfall shows considerable inter-annual variations throughout the period of observation. Large proportion of negative anomalies is observed in Kiremt rainfall (56\% of the total observations). Relatively, the 1990s is wet compared with the 1980 and 2000s. Drier conditions for Belg rainfall were experienced for the period 1986-1992 except the years 1989 and 1991. Wetter conditions for Belg were experienced for the period 1993-2000 except the year 1995 and 1998. Since 2007, positive anomalies are observed except the years 2010 and 2012. Positive and negative anomalies account for $56 \%$ and $44 \%$ of the total observations, respectively. The 1980 s is the driest decade for Belg.

Standardized monthly rainfall anomalies were also computed for the wettest and driest periods to assess extents of wetness and dryness in the watershed. As shown in Table 1, the driest and wettest years over the

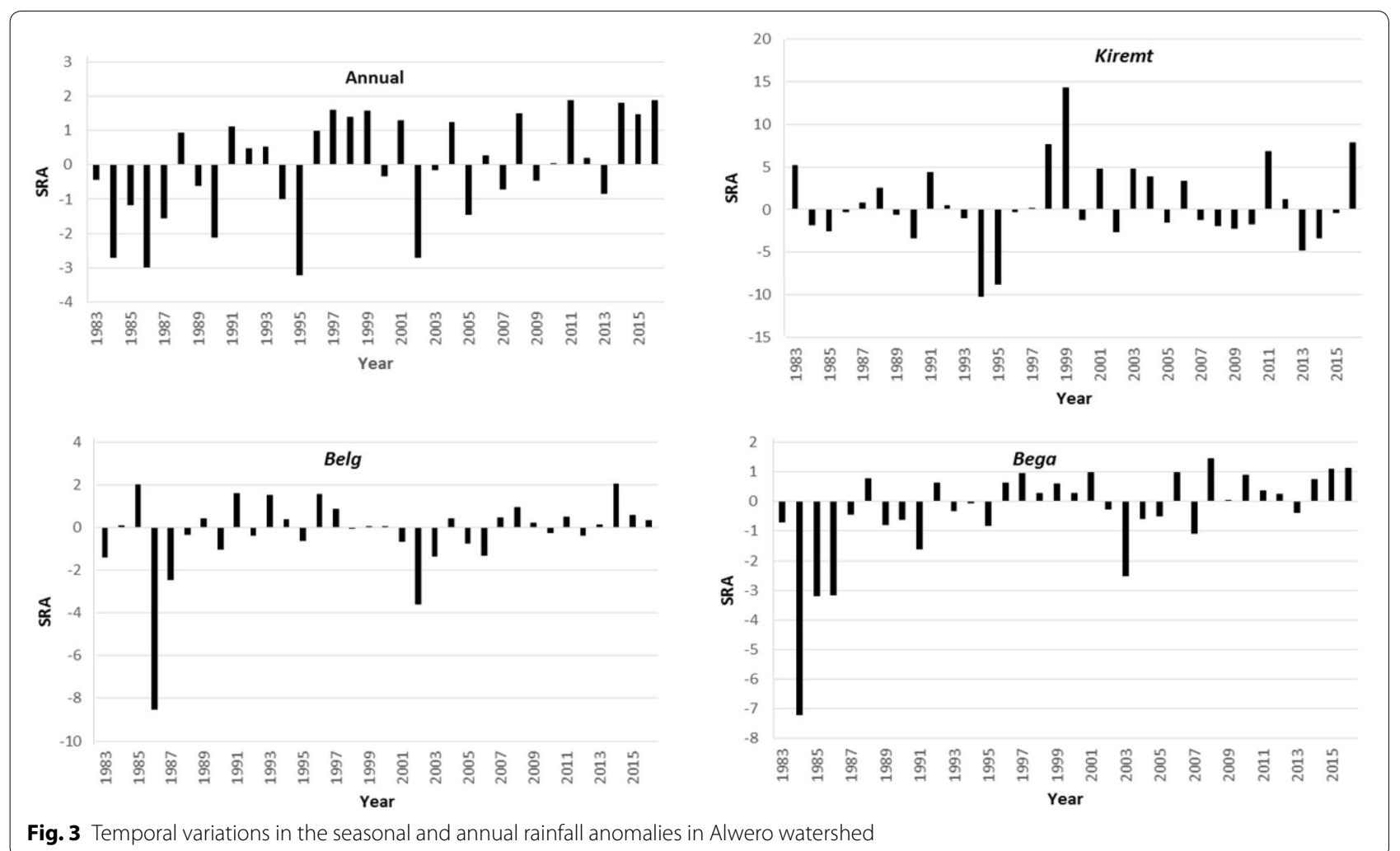


period of observation are 1986 and 2011, respectively. In the driest period the highest and the lowest SRA values are 1.45 and -1.25 , respectively, while the highest and the lowest SRA values during the wettest period are 1.26 and -1.19 , respectively. The highest and the lowest SRA during driest years are observed during June and January, respectively. May and February observed the highest and the lowest SRA values during the wettest years. About $67 \%$ of observations showed below average rainfall during the driest period, but only $25 \%$ of the observations fall under the different drought categories. About 50\% of the observations showed below average rainfall during the wettest period. From these, nearly $33 \%$ fall under the different drought categories. This shows that rainfall concentration is not uniform and few months remain dry even in years of good rain conditions.

Figure 4 and Table 2 show the spatial distribution of annual rainfall over the period of analysis. East and southeast part of the watershed receive high amount of annual rainfall. More than half of the watershed receives annual rainfall of $1550-1700 \mathrm{~mm}$. Another large proportion of the watershed (26\%) receives annual rainfall of between 1411 and $1550 \mathrm{~mm}$. More than $20 \%$ of the watershed receives annual rainfall of between 1700 and $1850 \mathrm{~mm}$. About $1 \%$ of the watershed receives annual rainfall of $>2000 \mathrm{~mm}$. The spatial distribution of Belg and Bega seasons reveals similar pattern in which rainfall increases from west to east. Almost all parts of the lower sub watershed receive Kiremt rainfall $>950 \mathrm{~mm}$ over the period of observation. The northern part of the upper sub watershed receives Kiremt rainfall of 768-850 mm.

\section{Trends in annual and seasonal rainfall in the upper (eastern)} sub-watershed

Mean annual rainfall of upper sub-watershed is $1686.2 \mathrm{~mm}$ with coefficient of variation of $8.9 \%$ which
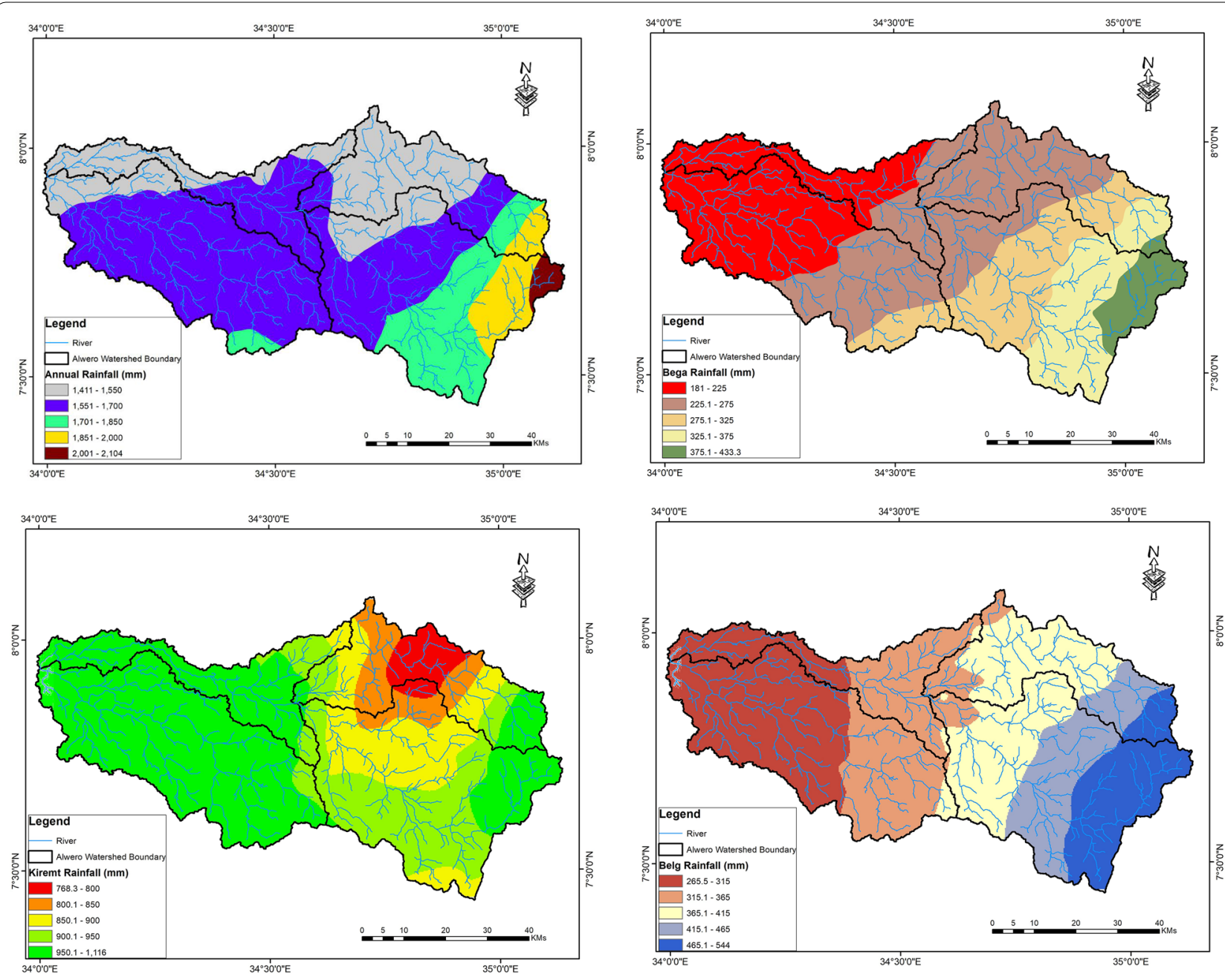

Fig. 4 Spatial distribution of annual and seasonal rainfall in Alwero watershed 
Table 2 Rainfall distribution in Alwero watershed

\begin{tabular}{|c|c|c|c|c|c|c|}
\hline \multirow[t]{2}{*}{ Rainfall Class } & \multicolumn{2}{|c|}{ Upper (eastern) sub-watershed } & \multicolumn{2}{|c|}{ Lower (western) subwatershed } & \multicolumn{2}{|c|}{ Alwero watershed } \\
\hline & Area (ha) & $\%$ & Area (ha) & $\%$ & Area (ha) & $\%$ \\
\hline $1411-1550 \mathrm{~mm}$ & $77,962.5$ & 28.6 & $54,650.0$ & 22.7 & $132,612.5$ & 25.8 \\
\hline $1550-1700 \mathrm{~mm}$ & $87,243.8$ & 32.0 & $180,487.5$ & 75.0 & $267,731.3$ & 52.2 \\
\hline $1700-1850 \mathrm{~mm}$ & $68,800.0$ & 25.3 & 5431.3 & 2.3 & $74,231.3$ & 14.5 \\
\hline 1850-2000 mm & $32,131.3$ & 11.8 & 0.0 & 0.0 & $32,131.3$ & 6.3 \\
\hline 2000-2104 mm & 6318.8 & 2.3 & 0.0 & 0.0 & 6318.8 & 1.2 \\
\hline Total & $272,456.3$ & 100.0 & $240,568.8$ & 100.0 & $513,025.0$ & 100.0 \\
\hline
\end{tabular}

shows low inter-annual variability. Kiremt and Belg rainfalls show low inter-annual variability of $9 \%$ and $19 \%$, respectively. Only Bega rainfall shows moderate interannual variability with coefficient of variation of $24 \%$. Kiremt rainfall contributes the largest to the annual rainfall (55\%), which is followed by Belg (26\%) and Bega (19\%), respectively. The driest and wettest periods over the period of observation are $1986(1419.3 \mathrm{~mm})$ and 2016 $(1987 \mathrm{~mm})$, respectively. Annual rainfall shows statistically significant increasing trend at $p=0.05$ level, while Bega rainfall also shows statistically significant increasing trend at $p=0.01$ level. Belg and Kiremt rainfalls show statistically non-significant increasing and decreasing tendencies, respectively (Fig. 5).

More than $85 \%$ of the upper sub-watershed receives annual rainfall of between 1411 and $1850 \mathrm{~mm}$. The other $12 \%$ of the upper sub-watershed receives annual rainfall of between 1850 and $2000 \mathrm{~mm}$. The remaining $2 \%$ of the upper sub-watershed receives annual rainfall of $>2000 \mathrm{~mm}$ (Fig. 4 and Table 2).

Annual rainfall shows considerable inter-annual variations since 2000. Positive annual rainfall anomalies accounts for $50 \%$ of the total observations for the period 1983-2016. The 1980s is the driest decade. Bega rainfall anomalies show similar pattern with annual rainfall anomalies. Positive Bega rainfall anomalies accounts for $50 \%$ of the total observations. Kiremt rainfall shows considerable inter-annual variations throughout the period of observation. Kiremt rainfall has the smallest proportion of positive anomalies (44\%). The 2000s is the driest decade. Belg rainfall shows considerable inter-annual variations. However, large proportion of positive rainfall anomalies is observed (56\%). Since 2007 positive rainfall anomalies are observed except the years 2010 and 2012.

\section{Trends in annual and seasonal rainfall in the lower (western)} sub-watershed

Mean annual rainfall of the lower sub-watershed is $1600.6 \mathrm{~mm}$. Annual rainfall shows low inter-annual variability (10.9\%). Kiremt rainfall also shows low inter-annual variability (12.5\%). Belg and Bega rainfalls show moderate inter-annual variability with coefficient of variation of 29 and 32\%, respectively. Kiremt rainfall contributes the largest to the annual rainfall (67\%). Belg and Bega contribute the remaining 19 and $14 \%$ of annual rainfall, respectively. The driest and wettest periods over the period of observation are $1995(1179 \mathrm{~mm})$ and 1991 (1857 $\mathrm{mm})$, respectively. Annual and Kiremt rainfalls show statistically non-significant increasing trend, while Bega rainfall shows statistically significant increasing trend at $p=0.01$ level (Fig. 5).

Large part of the lower sub-watershed (75\%) receives annual rainfall of between 1411 and $1550 \mathrm{~mm}$, and about $23 \%$ receives annual rainfall of between 1550 and $1700 \mathrm{~mm}$. A small portion of the lower sub-watershed receives annual rainfall of between 1700 and $1850 \mathrm{~mm}$ (Fig. 4 and Table 2).

Annual rainfall shows considerable inter-annual variations from 1983-2009. Positive annual rainfall anomalies accounts for $59 \%$ of observations. The 2000 s is the wettest decade. Positive anomalies are observed since 2007 except the year 2009. The 2000s is the driest decade for Belg and Bega rainfall. The proportion of positive and negative anomalies for Belg and Bega rainfalls are 44\% and $56 \%$ of the observations, respectively. Positive anomalies for Kiremt rainfall account for 53\% of observations. The 1990s is the wettest decade.

\section{Temperature trends in Alwero watershed}

In the watershed, the mean annual temperature is $25.0^{\circ} \mathrm{C}$. Over the study period, the lowest and highest mean annual temperatures are experienced in 2016. The lowest temperature is $14.5{ }^{\circ} \mathrm{C}$ (January) with standard deviation of 0.096 and coefficient of variation of 0.05 . The highest temperature is $39.3^{\circ} \mathrm{C}$ (March) with standard deviation of 0.1 and coefficient of variation of 0.03 . Mean annual minimum temperature ranges from $16.7^{\circ} \mathrm{C}(2001)$ to $18.5^{\circ} \mathrm{C}(1984)$, and the long term mean is $17.5^{\circ} \mathrm{C}$ with standard deviation of 0.4 and coefficient of variation of 0.03. Mean annual maximum temperature ranges from 

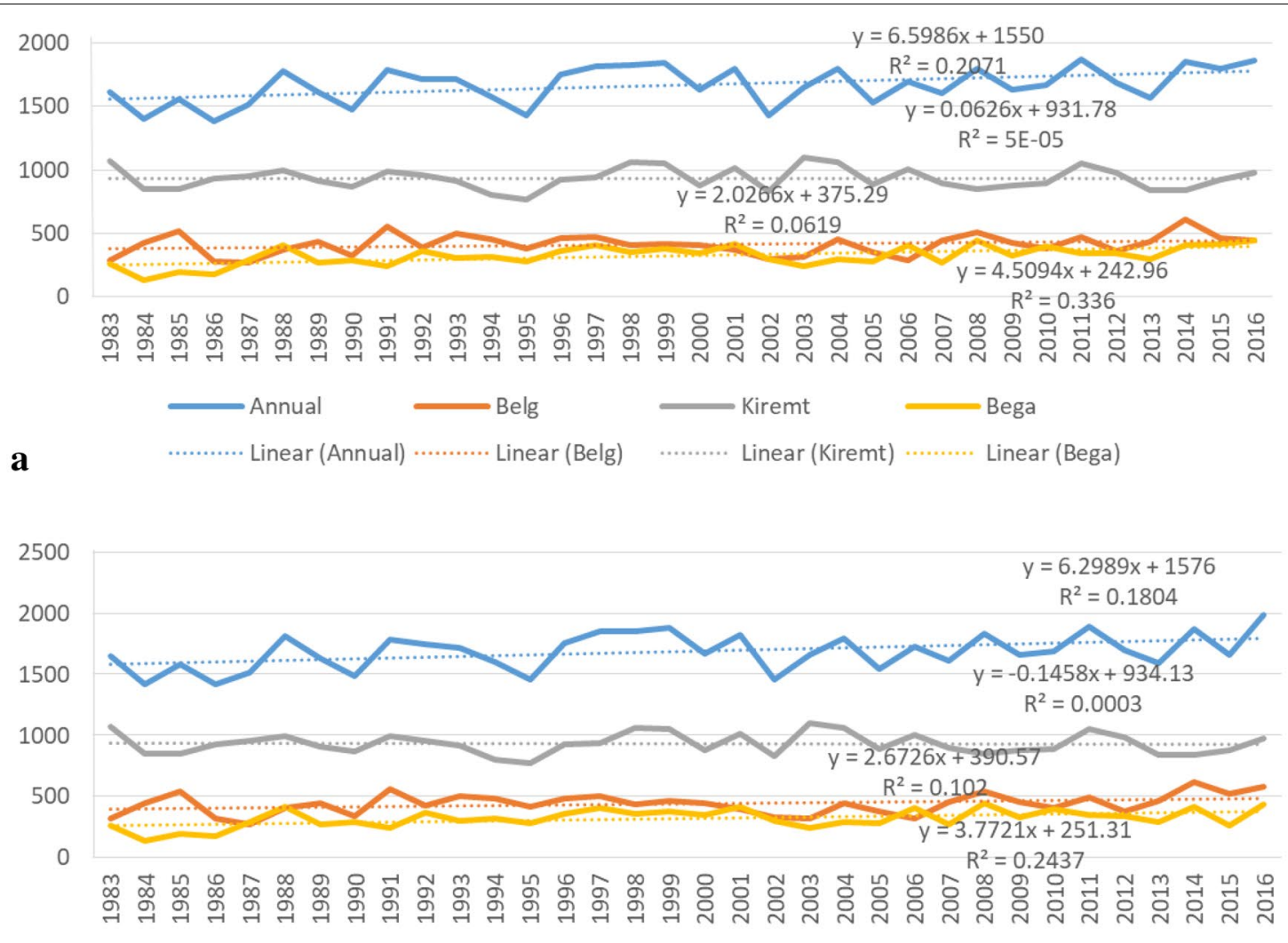

b
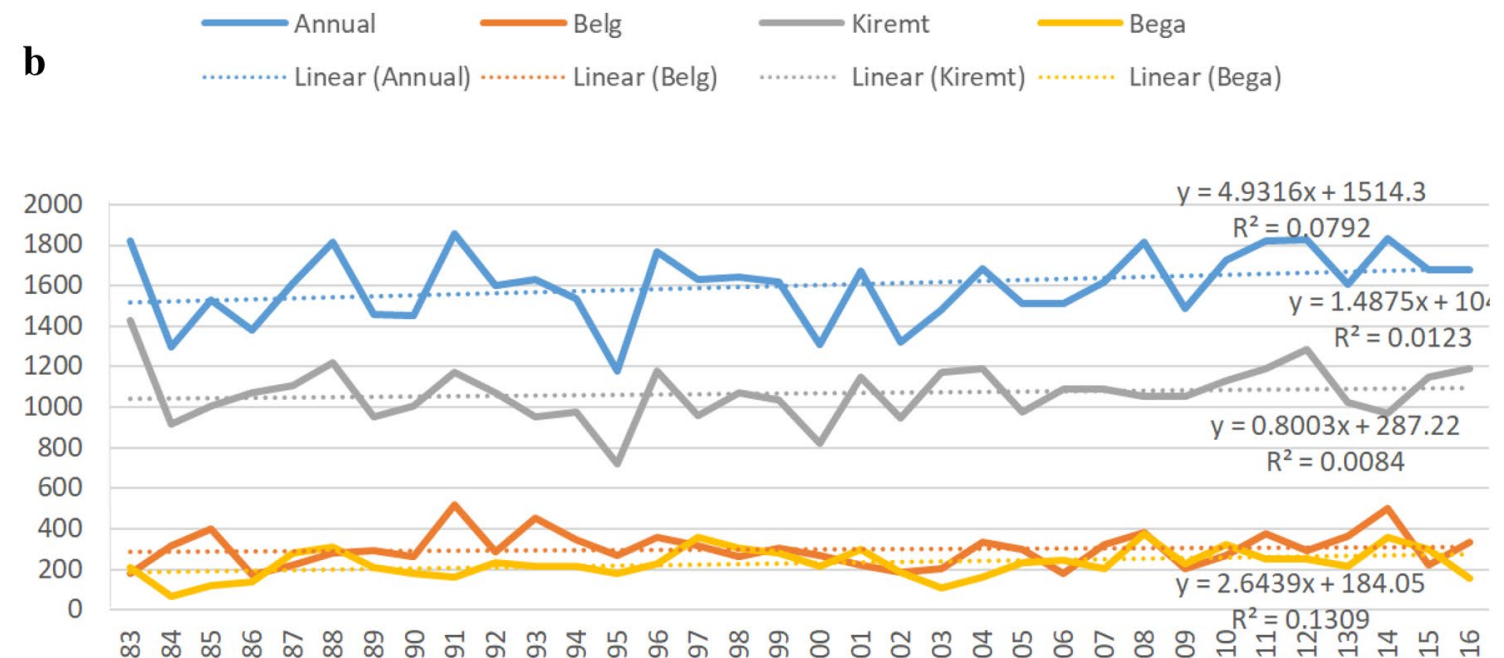

œ

c
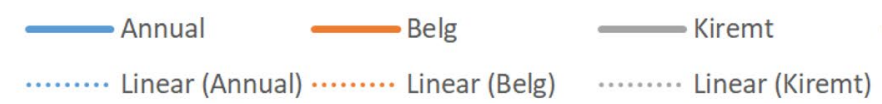

- Bega

Fig. 5 a Trends of annual and seasonal rainfall in Alwero watershed. $\mathbf{b}$ Trends of annual and seasonal rainfall in the lower sub watershed. c The Trends of annual and seasonal rainfall in the upper sub watershed

$31.4{ }^{\circ} \mathrm{C}$ (2008) to $33.2{ }^{\circ} \mathrm{C}(1999)$, and the long term mean is $32.5^{\circ} \mathrm{C}$ with standard deviation of 0.46 and coefficient of variation of 0.01 .
Unexpectedly, the mean annual minimum and maximum temperatures show statistically non-significant declining trends. Statistically non-significant but decreasing trends in all seasons are also observed in the 
minimum temperature. Bega season experienced statistically significant deceasing trend in the maximum temperature at $p=0.01$ level. Belg season experienced statistically non-significant but decreasing trend in the maximum temperature. Statistically non-significant but increasing trend is also observed for the Kiremt (Table 3).

Our finding of declining trends in the mean maximum and minimum temperatures contradicts the results reported by NMA (2007), McSweeney et al. (2008), Taye and Zewdu (2012), Ayalew et al. (2012), Mengistu et al. (2013), Mekasha et al. (2014), Addisu et al. (2015), Alemayehu and Bewket (2017a), Asaminew et al. (2017), Suryabhagavan (2017), Haile et al. (2019) and Matewos and Tefera (2020) who reported warming trends in the minimum and maximum temperatures in different parts of the country. Our research is unable to explain this result.

Figure 6 shows the year-to-year variability in the mean annual minimum temperature. The 1980s was the warmest decade compared to the 1990 and 2000s. Positive and negative anomalies account for $38 \%$ and $62 \%$ of the total observations, respectively. Seasonal anomalies in the minimum temperature have similar patterns to anomalies in the annual minimum temperature. Kiremt season anomalies are positive since 2005 except the years 2008 and 2011. The maximum number of negative anomalies is observed in Bega season (59\%).

The year-to-year variability in the mean annual maximum temperature is shown in Fig. 7. From 1998-2005 standardized anomalies are positive, and then negative

Table 3 Trends in annual and seasonal maximum and minimum temperatures in Alwero watershed

\begin{tabular}{lllllllll}
\hline & \multicolumn{1}{l}{ Temperature $\left({ }^{\circ} \mathbf{C}\right)$} & & & & \\
\cline { 2 - 9 } & Annual & LT & Belg & LT & Bega & LT & Kiremt & LT \\
\hline Minimum & 17.51 & -0.06 & 18.50 & -0.17 & 17.05 & -0.014 & 17.3 & -0.04 \\
Maximum & 32.46 & -0.01 & 34.45 & -0.09 & 33.17 & $-0.24^{* *}$ & 30.07 & 0.06 \\
\hline
\end{tabular}

** Significant at 0.01 level; $L T$ linear trend ( $C$ /10 yr)

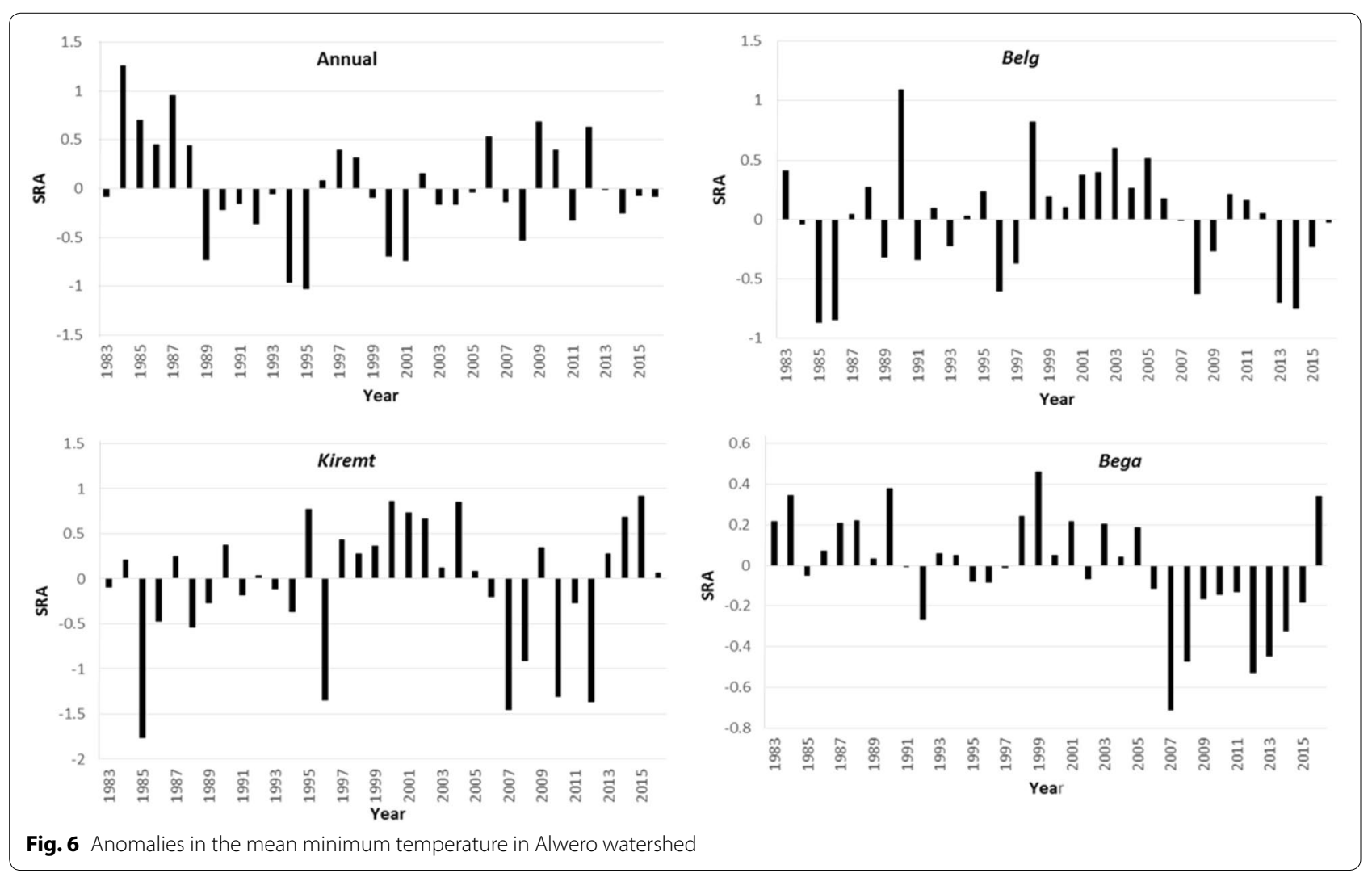




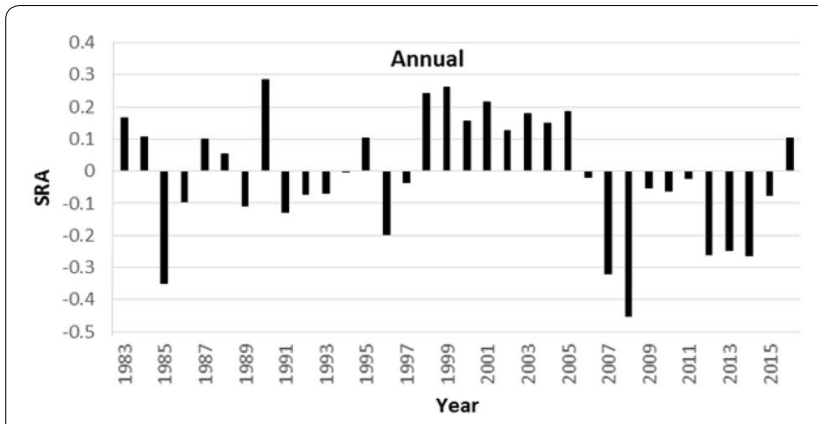

Kiremt

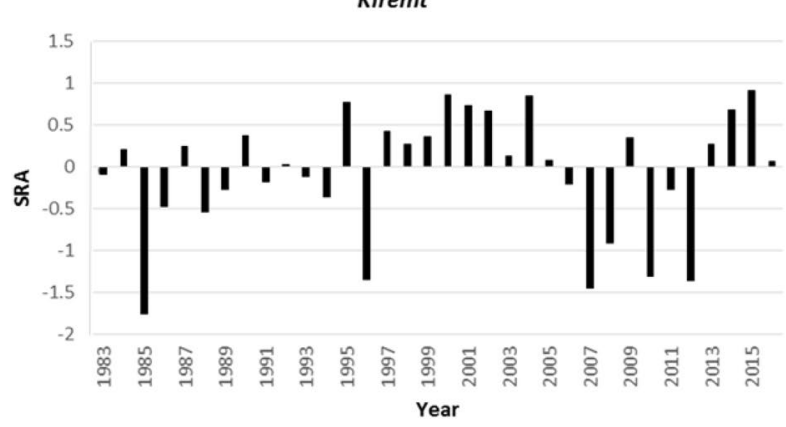

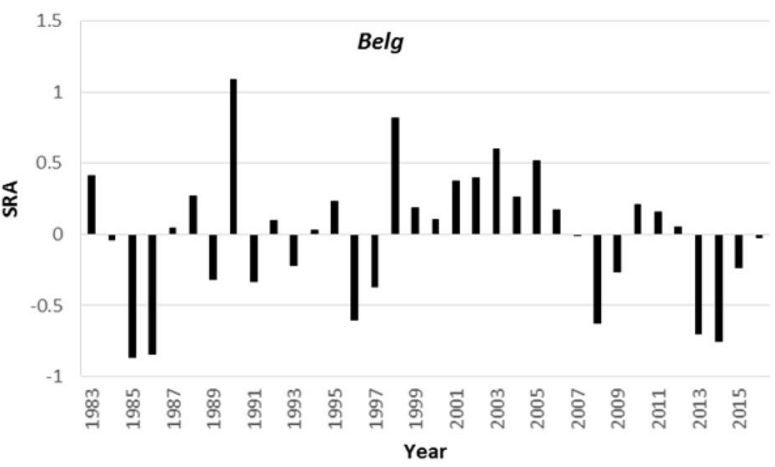

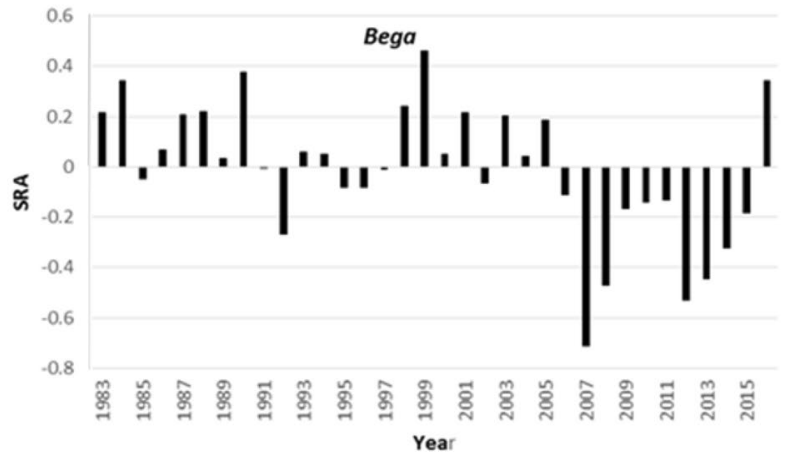

Fig. 7 Anomalies in the mean maximum temperature in Alwero watershed

since 2006 except 2016. Positive and negative anomalies account for 44 and $56 \%$ of the total observations, respectively. The 2000 s are cooler than the preceding decade. Seasonal anomalies in the maximum temperatures have similar patterns to mean annual maximum temperatures. Seasonal negative temperature anomalies range from $44 \%$ (Belg) to $53 \%$ (Bega).
Cooling conditions are observed for Bega season from 2006-2015.

\section{Spatial patterns of temperature}

Figure 8 shows the spatial distribution of mean maximum and minimum temperatures. The mean maximum and minimum temperatures decrease from west to east.
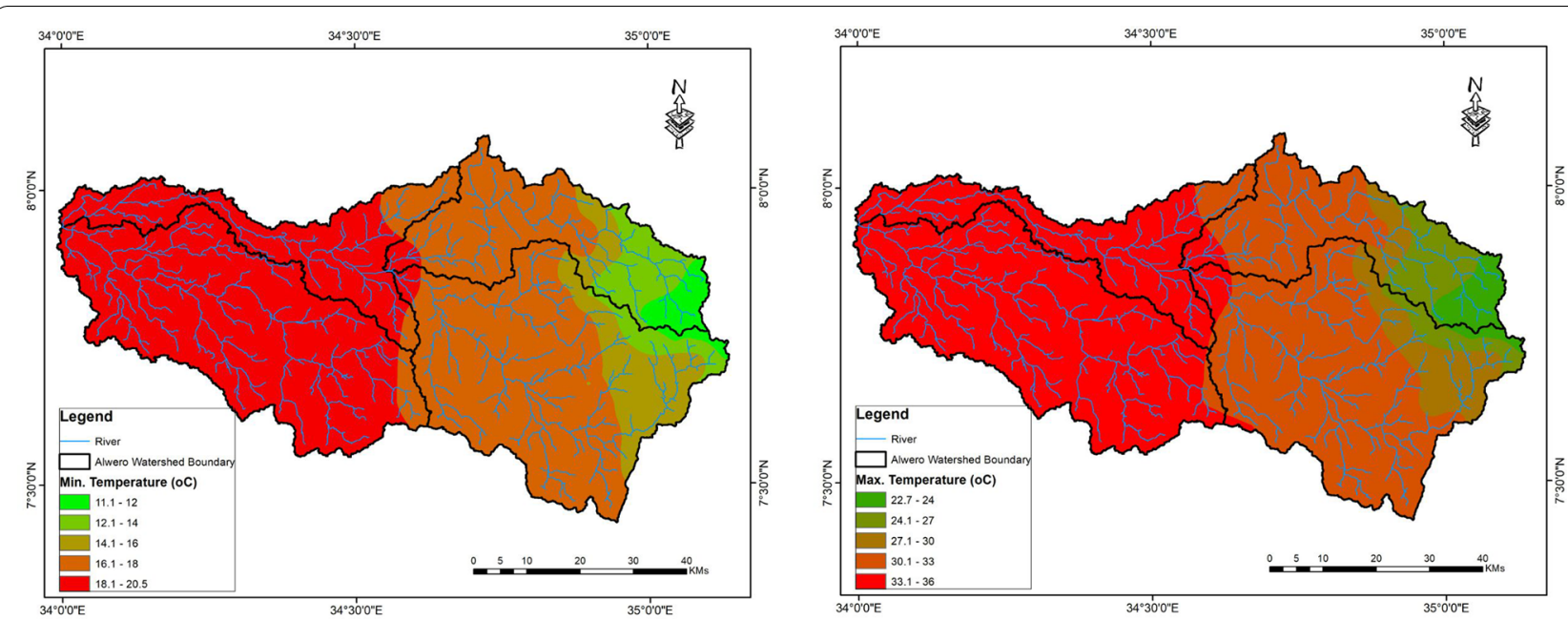

Fig. 8 Spatial distribution of maximum (left) and minimum (right) temperatures in Alwero watershed 
Large proportion of Alwero watershed (44.5\%) experiences mean minimum temperature of $18.1-20.5{ }^{\circ} \mathrm{C}$. About $39.4 \%$ of the area experiences mean minimum temperature of $16.1-18{ }^{\circ} \mathrm{C}$. A small proportion of the watershed $(2.4 \%)$ experiences mean minimum temperature of $11.1-12{ }^{\circ} \mathrm{C}$. About $47 \%$ of the watershed experiences mean maximum temperature of $33.1-36{ }^{\circ} \mathrm{C}$. Another large proportion of the watershed (38\%) experiences mean maximum temperature of $30.1-33{ }^{\circ} \mathrm{C}$. Less than $3 \%$ of the watershed experiences maximum temperature of $22.7-24{ }^{\circ} \mathrm{C}$.

\section{Temperature trends in the upper (eastern) sub watershed}

The mean annual temperature in the upper sub watershed varies from $22.53{ }^{\circ} \mathrm{C}$ (2008) to $23.81{ }^{\circ} \mathrm{C}$ (1984). The mean annual temperature over the period of observation is $23.25{ }^{\circ} \mathrm{C}$ with standard deviation of $0.31{ }^{\circ} \mathrm{C}$ and coefficient of variation of $0.01{ }^{\circ} \mathrm{C}$. The highest mean maximum temperature is $31.04{ }^{\circ} \mathrm{C}$ (2016). Conversely, the lowest mean minimum temperature over the period of observation is $15.33{ }^{\circ} \mathrm{C}$ (1994). The mean annual and seasonal maximum temperatures show statistically significant declining trends except Kiremt season which shows statistically non-significant but increasing trend. The decreasing trend in Bega season is statistically significant at $p=0.05$ level. The deceasing trends in Belg season and annual maximum temperatures are significant at $p=0.1$ level. The mean annual and seasonal minimum temperatures show statistically non-significant declining trends except Belg season which shows statistically significant declining trend at $p=0.05$ level. Large part of the upper sub watershed (98\%) experiences mean minimum temperature of $11-18{ }^{\circ} \mathrm{C}$. The remaining $2 \%$ of the area experiences mean minimum temperature of $18.1-21{ }^{\circ} \mathrm{C}$. Over $70 \%$ of the sub watershed experiences mean maximum temperature of $30-36{ }^{\circ} \mathrm{C}$. The remaining part of the sub watershed experiences maximum temperature of 23-30 ${ }^{\circ} \mathrm{C}$ (Tables 4 and 5 and Fig. 9). Seasonal anomalies in the maximum and minimum temperatures have similar patterns to mean annual maximum and minimum temperatures of the respective watersheds.

\section{Temperature trends in the lower (western) sub watershed}

The mean annual temperature in the lower sub watershed ranges from $26.6{ }^{\circ} \mathrm{C}$ (2009) to $28.13{ }^{\circ} \mathrm{C}$ (1985). The mean annual temperature over the period of observation is $27.39{ }^{\circ} \mathrm{C}$ with standard deviation of $0.38{ }^{\circ} \mathrm{C}$ and coefficient of variation of $0.01{ }^{\circ} \mathrm{C}$. The highest mean maximum temperature is $36.59{ }^{\circ} \mathrm{C}$ (1991). Conversely, the lowest mean minimum temperature in the lower sub watershed over the period of observation is $18.61{ }^{\circ} \mathrm{C}(1990)$. The mean annual and seasonal maximum temperatures show decreasing trends. The decreasing trends in Bega season and annual maximum temperatures are statistically significant at $p=0$ 01 and $p=0.05$ levels, respectively. The mean annual

Table 4 Minimum temperature distribution in Alwero watershed

\begin{tabular}{|c|c|c|c|c|c|c|}
\hline \multirow[t]{2}{*}{ Min temp class } & \multicolumn{2}{|c|}{ Upper (eastern) sub watershed } & \multicolumn{2}{|c|}{ Lower (western) sub watershed } & \multicolumn{2}{|c|}{ Alwero watershed } \\
\hline & $\mathrm{Ha}$ & $\%$ & $\mathrm{Ha}$ & $\%$ & $\mathrm{Ha}$ & $\%$ \\
\hline $11.1-12^{\circ} \mathrm{C}$ & $12,281.3$ & 4.5 & 0.0 & 0.0 & $12,281.3$ & 2.4 \\
\hline $12.1-14^{\circ} \mathrm{C}$ & $28,681.3$ & 10.5 & 0.0 & 0.0 & $28,681.3$ & 5.6 \\
\hline $14.1-16^{\circ} \mathrm{C}$ & $41,743.8$ & 15.3 & 0.0 & 0.0 & $41,743.8$ & 8.1 \\
\hline $16.1-18^{\circ} \mathrm{C}$ & $184,081.3$ & 67.6 & $17,887.5$ & 7.4 & $201,968.8$ & 39.4 \\
\hline $18.1-20.5^{\circ} \mathrm{C}$ & 5668.8 & 2.1 & $222,681.3$ & 92.6 & $228,350.0$ & 44.5 \\
\hline Total & $272,456.3$ & 100.0 & $240,568.8$ & 100.0 & $513,025.0$ & 100.0 \\
\hline
\end{tabular}

Table 5 Maximum temperature distribution in Alwero watershed

\begin{tabular}{|c|c|c|c|c|c|c|}
\hline \multirow[t]{2}{*}{ Max temp class } & \multicolumn{2}{|c|}{ Upper (eastern) sub watershed } & \multicolumn{2}{|c|}{ Lower (Western) sub watershed } & \multicolumn{2}{|c|}{ Alwero watershed } \\
\hline & $\mathrm{Ha}$ & $\%$ & $\mathrm{Ha}$ & $\%$ & $\mathrm{Ha}$ & $\%$ \\
\hline $22.7-24^{\circ} \mathrm{C}$ & $14,525.0$ & 5.3 & 0.0 & 0.0 & $14,525.0$ & 2.8 \\
\hline $24.1-27^{\circ} \mathrm{C}$ & $28,931.3$ & 10.6 & 0.0 & 0.0 & $28,931.3$ & 5.6 \\
\hline $27.1-30^{\circ} \mathrm{C}$ & $34,900.0$ & 12.8 & 0.0 & 0.0 & $34,900.0$ & 6.8 \\
\hline $30.1-33^{\circ} \mathrm{C}$ & $183,287.5$ & 67.3 & 9243.8 & 3.8 & $192,531.3$ & 37.5 \\
\hline $33.1-36^{\circ} \mathrm{C}$ & $10,812.5$ & 4.0 & $231,325.0$ & 96.2 & $242,137.5$ & 47.2 \\
\hline Total & $272,456.3$ & 100.0 & $240,568.8$ & 100.0 & $513,025.0$ & 100.0 \\
\hline
\end{tabular}




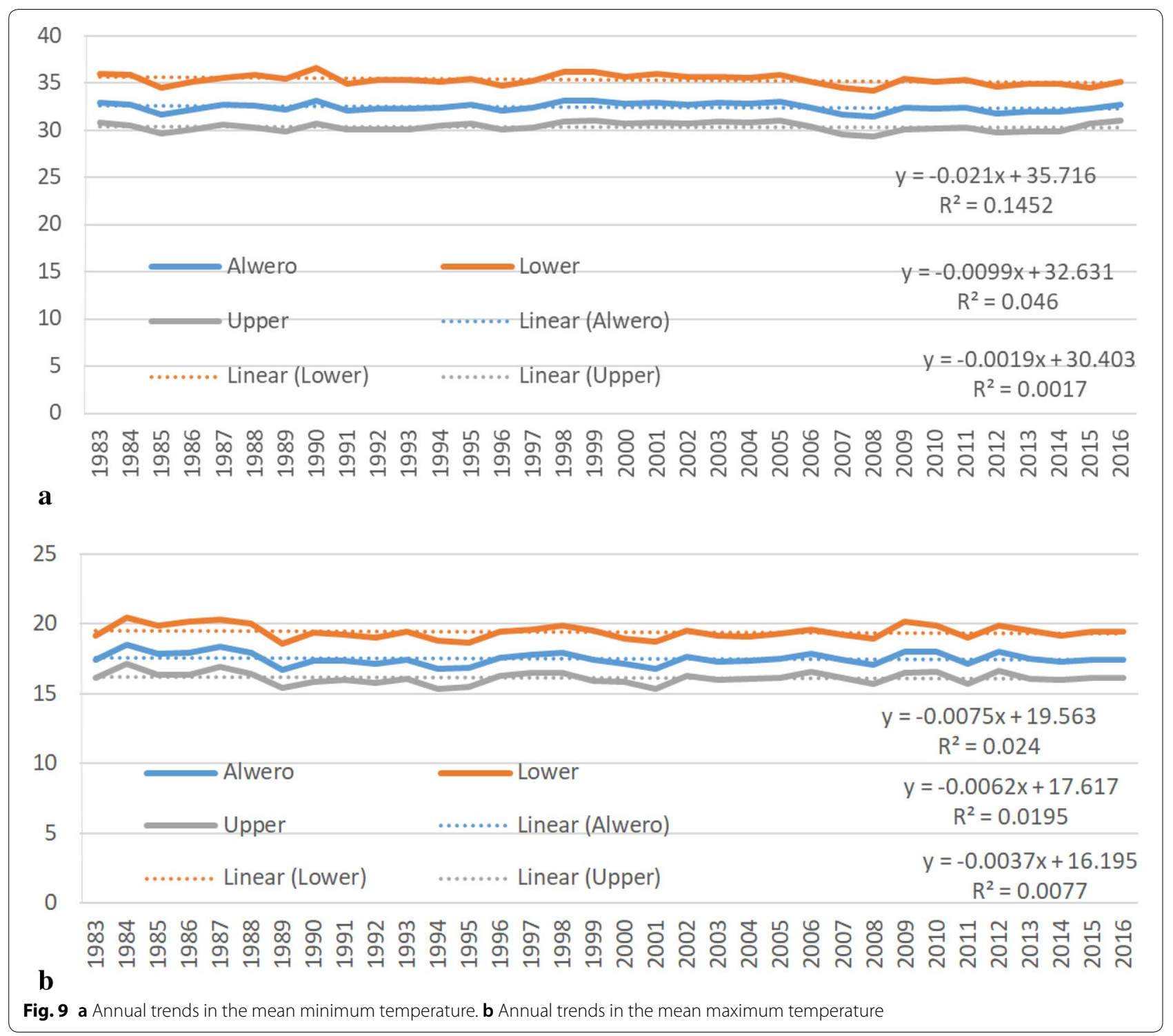

and seasonal minimum temperatures show statistically non-significant declining trends except Bega season which shows statistically non-significant but increasing trend. Large proportion of the lower sub watershed (93\%) experiences mean minimum temperature of $18-21{ }^{\circ} \mathrm{C}$ while the remaining $7 \%$ of the lower sub watershed experiences mean minimum temperature of $16-18{ }^{\circ} \mathrm{C}$. Almost $96 \%$ of the area experiences mean maximum temperature of $33-36{ }^{\circ} \mathrm{C}$. The remaining $4 \%$ of the lower sub watershed experiences mean maximum temperature of $30-33{ }^{\circ} \mathrm{C}$ (Tables 4 and 5 and Fig. 9).

The innovative element of this study is the use of gridded monthly rainfall and maximum and minimum temperature data series at a resolution of $4 \times 4 \mathrm{~km}$ which are created by blending station records with meteorological satellite estimates. This is the best available dataset for the country recommended for climate analysis. The methodology used is well established, standard, proven, and widely used by many researchers. It has the advantage of making good results. However, the methodology and results are new to the study area. Our analysis focuses on local scale climatology and the findings are useful for climate risk management. The findings can be applicable to other parts of rural Ethiopia as well. In particular, the analysis is useful for irrigation and investment as the area is the largest agricultural investment hub in the country. 


\section{Conclusions}

This study presents analysis of spatiotemporal variability and trends in rainfall and temperature in Alwero watershed, western Ethiopia. The key findings and conclusions are the following;

1. Mean annual rainfall of Alwero watershed is $1665.5 \mathrm{~mm}$. More than half of the watershed receives annual rainfall of 1550-1700 mm. Annual and seasonal rainfall show low inter-annual variability except for Bega which shows moderate coefficient of variation. Annual and Bega rainfall shows statistically significant increasing trend at $p=0.01$ level. Belg rainfall shows statistically non-significant increasing trend. There is no clear trend in Kiremt rainfall. Regarding monthly rainfall trends, May, November and October showed statistically significant increasing trends while March showed statistically significant decreasing trend. Positive and negative anomalies in annual rainfall account for $53 \%$ and $47 \%$ of the total observations, respectively. About $29 \%$ of the total observations is under the different drought categories. The 1990s is wet compared to the 1980 and 2000s.

2. The mean annual temperature of the watershed is $25{ }^{\circ} \mathrm{C}$ with a standard deviation of 0.31 and coefficient of variation of 0.01 . In the watershed, mean annual minimum and maximum temperatures show statistically non-significant decreasing trends. The year-to-year variability in the mean annual minimum and maximum temperatures showed that the 2000s is cooler than the preceding decades. Seasonal anomalies in the mean minimum and maximum temperatures have similar patterns to mean annual minimum and maximum temperatures. The mean maximum and minimum temperatures decrease from west to east. Large proportion of Alwero watershed (44.5\%) experiences mean minimum temperature of 18.1$20.5{ }^{\circ} \mathrm{C}$. Another large proportion of the watershed (38\%) experiences mean maximum temperature of $30.1-33^{\circ} \mathrm{C}$.

3. Overall, it is shown that climatic variability and trends are highly localized in the country; hence local level studies such as this are important for practical decision making in agriculture, water management, and climate change adaptation planning.

\section{Abbreviation}

NMA: National Meteorological Agency.

\section{Acknowledgements}

The authors would like to thank the National Meteorological Agency of Ethiopia for providing the climate data.

\section{Authors' contributions}

MM has made substantial contributions in conception of the research, acquisition of data and preparation of maps. AA interpreted the results and drafted the manuscript. WB and MA reviewed, edited and shaped the manuscript. All authors read and approved the final manuscript.

\section{Funding}

This study received no external funding.

\section{Availability of data and materials}

The datasets used in the study are available in the National Meteorological Agency (NMA) of Ethiopia repository. Access to NMA data can be allowed based on justifiable request. However, the datasets used and/or analysed during the current study are available from the corresponding author on reasonable request.

\section{Ethics approval and consent to participate}

Not applicable.

\section{Consent for publication}

Not applicable.

\section{Competing interests}

No potential conflict of interest was reported by the authors.

\section{Author details}

${ }^{1}$ Department of Geography \& Environmental Studies, Debre Berhan University, Debre Birhan, Ethiopia. ${ }^{2}$ Department of Geography \& Environmental Studies, Addis Ababa University, Addis Ababa, Ethiopia.

Received: 17 July 2020 Accepted: 15 September 2020

Published online: 25 September 2020

\section{References}

Addisu S, Selassie GY, Fissha G, Gedif B (2015) Time series trend analysis of temperature and rainfall in Lake Tana Sub-basin Ethiopia. Environ Syst Res 4(25):1-12

Ademe D, Ziatchik B, Tesfaye K, Simane B, Alemayehue G, Adgoe A (2020) Climate trends and variability at adaptation scale: Patterns and perceptions in an agricultural region of the Ethiopian Highlands. Weather Clim Extremes 29:100263

Admassu S (2004) Rainfall variation and its effect on crop production in Ethiopia. MSc Thesis, Addis Ababa: Addis Ababa University.

Agnew C, Chappel A (1999) Drought in the Sahel. GeoJournal 48(4):299-311

Alemayehu A, Bewket W (2016a) Local climate variability and crop production in the central highlands of Ethiopia. Environ Dev 19:36-48

Alemayehu A, Bewket W (2016b) Vulnerability of smallholder farmers' to climate change and variability in the central highlands of Ethiopia. EJSSH 12(2):1-24

Alemayehu A, Bewket W (2017a) Local spatiotemporal variability and trends in rainfall and temperature in the central highlands of Ethiopia. Geogra Ann Series A Phys Geogr 99(2):85-101

Alemayehu A, Bewket W (2017b) Determinants of smallholder farmers' choice of coping and adaptation strategies to climate change and variability in the central highlands of Ethiopia. Environ Dev 24:77-85

Asaminew TG, Araya A, Atkilt G, Solomon H (2017) Modelling the potential impact of climate change on cotton (Gossypium hirsutum) production in northeastern semi-arid Afar and western Tigray regions of Ethiopia. J Earth Sci Clim Change 8:390

Asfaw A, Simane B, Hassen A, Bantider A (2018) Variability and time series trend analysis of rainfall and temperature in north central Ethiopia: a case study in Woleka sub-basin. Weather Clim Extremes 19:29-41

Ayalew D, Tesfaye K, Mamo G, Yitaferu B, Bayu W (2012) Variability of rainfall and its current trend in Amhara region. Ethiopia Afr J Agric Res 7(10):475-1486

Bekele-Biratu E, Thiaw WM, Korecha D (2018) Sub-seasonal variability of the Belg rains in Ethiopia. Int J Climatol 38(7):2940-2953 
Bewket W, Conway D (2007) A note on the temporal and spatial variability of rainfall in the drought-prone Amhara region of Ethiopia. Int I Climatol 27(11):1467-1477

Bewket W (2009) Rainfall variability and crop production in Ethiopia: Case study in the Amhara region. In: Ege S, Aspen H, Teferra B, Bekele S (eds) Proceedings of the 16th International Conference of Ethiopian Studies

Chen H, Sun J, Chen X (2014) Projection and uncertainty analysis of global precipitation-related extremes using CMIP5 models. Int J Climatol 34(8):2730-2748

Cheung WH, Senay GB, Singh A (2008) Trends and spatial distribution of annual and seasonal rainfall in Ethiopia. Int J Climatol 28(13):1723-1734

Conway D, Schipper E (2011) Adaptation to climate change in Africa: Challenges and opportunities identified from Ethiopia. Glob Environ Change 21(1):227-237

CSA (Central Statistical Agency) (2013) Population projection of Ethiopia for all regions at Woreda level from 2014-2017'. The Federal Democratic Republic of Ethiopia, Addis Ababa

Degefu A, Bewket W (2014) Variability and trends in rainfall amount and extreme event indices in the Omo-Ghibe River Basin, Ethiopia. Reg Environ Change 14(2):799-810

Degife A, Zabel F, Mauser W (2019) Land use scenarios and their effect on potential crop production: the case of Gambella region, Ethiopia. Agriculture 9:105

De Luis M, Raventós J, González-Hidalgo JC, Sánchez JR, Cortina J (2000) Spatial analysis of rainfall trends in the region of Valencia (East Spain). Int J Climatol 20(12):1451-1469

Dinku T, Hailemariam K, Maidment R, Tarnavsky E, Connor S (2014) Combined use of satellite estimates and rain gauge observations to generate high-quality historical rainfall time series over Ethiopia. Int J Climatol 34(7):2489-2504

Dorosh P, Rashid S (2013) Food and agriculture in Ethiopia: Progress and policy challenges IFPRI issue brief. University of Pennsylvania Press, Washington, pp 1-4

Engida AN, Esteves M (2011) Characterization and disaggregation of daily rainfall in the Upper Blue Nile Basin in Ethiopia. J Hydrol 399(3-4):226-234

Gamachu D (1988) Some patterns of altitudinal variation of climatic elements in the mountainous regions of Ethiopia. Mt Res Dev 8:131-138

Gebrechorkos SH, Hülsmann S, Bernhofer C (2020) Analysis of climate variability and droughts in East Africa using high-resolution climate data products. Global Planet Change 186:103130

Gissila T, Black E, Grimes D, Slingo J (2004) Seasonal forecasting of the Ethiopian summer rains. Int J Climatol 24:1345-1358

Gleixner S, Keenlyside N, Viste E, Korecha D (2017) The El Ni no effect on Ethiopian summer rainfall. Clim Dynam 49:1865-1883. https://doi. org/10.1007/s00382-016-3421-z

Guttman B (1999) Accepting the standardized precipitation index: a calculation algorithm 1. JAWRA 35(2):311-322

Hadgu G, Tesfaye K, Mamo G, Kassa B (2013) Trend and variability of rainfall in Tigray, Northern Ethiopia: analysis of meteorological data and farmers' perception. Acad J Environ Sci 1(8):159-171

Haile GG, Tang Q, Sun S, Huang Z, Zhange Z, Liu X (2019) Droughts in East Africa: causes, impacts and resilience. Earth-Sci Rev 193:146-161

Jury MR, Funk C (2013) Climatic trends over Ethiopia: regional signals and drivers. Int J Climatol 33(8):1924-1935

Korecha D (2013) Characterizing the predictability of seasonal climate in Ethiopia. PhD thesis, University of Bergen, Norway.

Lemi A (2005) Rainfall probability and agricultural yield in Ethiopia. East Afr Soc Sci Res Rev 21(1):57-96

Matewos T, Tefera T (2020) Local level rainfall and temperature variability in drought-prone districts of rural Sidama, central rift valley region of Ethiopia. Phys Geogr. https://doi.org/10.1080/02723646.2019.1625850

McSweeney C, New M, Lizcano G (2008) UNDP climate change country profiles: Ethiopia. http://countryprofiles.geog.ox.ac.uk
Mekasha A, Tesfaye K, Duncan AJ (2014) Trends in daily observed temperature and precipitation extremes over three Ethiopian eco-environments. Int J Climatol 34:1990-1999

Mengistu D, Bewket W, Lal R (2013) Recent spatiotemporal temperature and rainfall variability and trends over the Upper Blue Nile River Basin Ethiopia. Int J Climatol 34(7):2278-2292

Mulugeta S, Fedler C, Ayana M (2019) Analysis of long-term trends of annual and seasonal rainfall in the Awash River Basin Ethiopia. Water 11:1498. https://doi.org/10.3390/w11071498

NMA (National Meteorological Agency) (1996) Climate \& agroclimate resources of Ethiopia. NMA Meteorological Research Report Series, Vol. 1, No. 1, Addis Ababa

NMA (National Meteorological Agency) (2007) Climate change: National Adaptation Program of Action (NAPA) of Ethiopia. Ministry of Water Resources, Addis Ababa

Osman M, Sauerborn P (2002) A preliminary assessment of characteristics and long term variability of rainfall in Ethiopia-Basis for sustainable land use and resource management. In: Paper Presented at Conference on International Agricultural Research for Development, Witzenhausen, Germany, October $9-11,2002$

Rahmato D (2011) Land to investors: Large-scale land transfers in Ethiopia. FSS Policy Debates Series No, 1. Addis Ababa: Forum for Social Studies

Reda D, Engida N, Asfaw H, Hamdi R (2015) Analysis of precipitation based on ensembles of regional climate model simulations and observational databases over Ethiopia for the period 1989-2008. Int J Climatol 35(6):948-971

Segele Z, Lamb P (2005) Characterization and variability of Kiremt rainy season over Ethiopia. Meteorol Atmos Phys 89:153-180

Seleshi Y, Zanke U (2004) Recent changes in rainfall and rainy days in Ethiopia. Int J Climatol 24(8):973-983

Shanko D, Camberlin P (1998) The effects of the Southwest Indian Ocean tropical cyclones on Ethiopian drought. Int J Climatol 18(12):1373-1388

Sun Q, Miao C, Duan Q, Ashouri H, Sorooshian S, Hsu KL (2018) A review of global precipitation data sets: data sources, estimation, and intercomparisons. Rev Geophys 56(1):79-107

Suryabhagavan KV (2017) GIS-based climate variability and drought characterization in Ethiopia over three decades. Weather Clim Extremes 15:11-23

Taye M, Zewdu F (2012) Spatio-temporal variability and trend of rainfall and temperature in Western Amhara, Ethiopia: a GIS approach. Glob Adv Res J Geogr Reg Plan 1(4):65-82

Urgessa GK (2013) Spatial and temporal uncertainty of rainfall in arid and semiarid areas of Ethiopia. Sci Technol Arts Res J 2(4):106-113

Verdin J, Funk C, Senay G, Choularton R (2005) Climate science and famine early warning. Philos Trans R Soc B Biol Sci 360(1463):2155-2168

Viste E, Korecha D, Sorteberg A (2012) Recent drought and precipitation tendencies in Ethiopia. Theoret Appl Climatol 112(3-4):535-551

Wagesho N, Goel NK, Jain MK (2013) Temporal and spatial variability of annual and seasonal rainfall over Ethiopia. Hydrol Sci J 58(2):354-373

World Bank (2006) Ethiopia: managing water resources to maximize sustainable growth. World Bank, Washington

Yitbarek T, Kibret K, Beyene S (2017) Physical land suitability evaluation for irrigation in the lower Alwero River area of Abobo, Western Ethiopia. Am J Agric For 5(3):60-64

Zabel F, Putzenlechner B, Mauser W (2014) Global agricultural land resources a high resolution suitability, evaluation and its perspectives until 2100 under climate change conditions. PLoS ONE 9(9):e107522

\section{Publisher's Note}

Springer Nature remains neutral with regard to jurisdictional claims in published maps and institutional affiliations. 